\section{White Earth Food Sovereignty Initiative: What food sovereignty looks like on the sovereign nation of White Earth}

Zachary Paige *

White Earth Band of Minnesota Chippewa Tribe
Special JAFSCD Issue

Indigenous Food Sovereignty in North America
sponsored by

Swette Center for
Sustainable Food Systems

Arizona State University

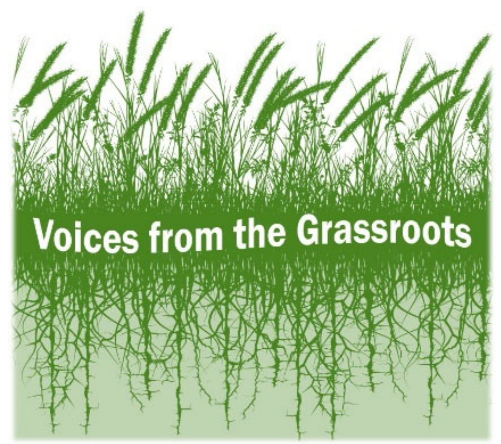

Submitted March 26, 2019 / Accepted March 26, 2019 / Published online December 16, 2019

Citation: Paige, Z. (2019). White Earth Food Sovereignty Initiative: What food sovereignty looks like on the sovereign nation of White Earth. Journal of Agriculture, Food Systems, and Community Development, 9(Suppl. 2), 19-23. https://doi.org/10.5304/jafscd.2019.09B.021

Copyright (C) 2019 by the Author. Published by the Lyson Center for Civic Agriculture and Food Systems. Open access under CC-BY license.

$\mathrm{H}$ ere in White Earth, we started our Food Sovereignty Initiative in the fall of 2017 to bring together and organize community-driven efforts that aid in establishing a sustainable and sovereign food system based in traditional methods of planting, gathering, harvest, hunting, and fishing - all protected by tribal policy.

We start our food sovereignty work primarily through gatherings with the White Earth community. Once a month, or sometimes once every two months when we are busy planting and gathering, we hold a potluck food sovereignty meeting (see Photo 1). Present are our core partners, such as the White Earth Tribal and Community College (WETCC) Extension Service, with whom we are

* Zachary Paige, Food Sovereignty Specialist, White Earth Band of Minnesota Chippewa Tribe; 1482 Highway 200; Mahnomen, Minnesota 56557 USA; zachary.paige@whiteearth-nsn.gov intertwined in many grants and commitments. Other partners include our White Earth health department, dieticians, nutritionists, SNAP-Ed, 4-H youth agriculture program, directors and managers in education, the agriculture department, natural resource department, commodity foods program, and the Elder Nutrition Program. Other partners include nonprofits, interested community members from White Earth, and others doing similar work coming from our neighboring reservations Leech Lake and Red Lake.

These food sovereignty meetings are also healing meetings. We do the best we can to prepare foods that are traditional or at least healthy. This is our time to sit and visit, things that are often lost in our busy technological age. At the meeting held in December 2018, we had some smoked goldeneye from Red Lake Fisheries, shared by David Manuel in Red Lake, canned venison sliders from the WETCC, wild rice and buffalo brats from White 
Earth, and quinoa salad from Diane McArthur, our White Earth nutritionist. We have fruitful conversations that are rooted in the true needs of our community, keeping us on track and building toward a grounded food system in White Earth. The conversations keep us engaged and empowered to make focused efforts and have an effect on the sometimes overwhelmingly broad need for a healthier food system. From time to time we also invite outside speakers from other organizations, University extension and researchers, the state agriculture department, who join us to learn about our community needs. Those attending our meetings regularly know that each of us is a slice, part of filling the big circle of food sovereignty. We all go back to our departments and families and play our role and expand upon our gifts that fit us as individuals and within the community. Then when we come back together, we share our experiences in increasing our communal understanding of our progress and how to work together effectively as a group. By having such an extraordinary and diverse group of community members focused on food sovereignty so close to the ground level come together regularly, we are able to act as branches on a connected system of roots, as we are all well aware that there is much work yet to be done.

The overall health of the White Earth community members is of vital importance. There are many areas of health: mental health, dietary health, disease treatment, physical improvement, as well as elder and youth care. We focus on food as a healing and universal glue to bring people together to heal our bodies, minds, spirit. There are sometimes challenges in accessing traditional and healthy food when living in the country-even when there are plenty of people gathering, planting, and hunting for themselves or their families. When observing food access from an eagle's view, the majority of the White Earth Reservation is a federally recognized food desert, because many people live upwards of 20 to 30 miles away from a big grocery store where most people shop for their daily foods. And even when shopping at those, there are limited traditional or healthy foods available.

Together, we created a food sovereignty assessment survey for the White Earth Reservation community members in 2017 and received over 250 responses (Figure 1). We will be able to use findings about our demographics in our dialogue moving forward. The responses also revealed the lack of cooking and reasons for the lack. We also found out that the White Earth community is very invested in all of the programs we suggested to aid in increasing traditional and healthy food access, including a farm-to-school program, a tribally shared agriculture program from a White Earth farm, and a mobile market grocery.

In 2017-2018, the White Earth Food Sovereignty Initiative (WEFSI) staff started with one person, Zachary Paige, as coordinator. With a limited staff we are limited in some ways, but we utilized many volunteers from the White Earth community and beyond to start our White Earth Community Pilot Farm. Volunteers include the Extension Service of WETCC, families and interested community members, the White Earth Natural Resource Department, the ACUTE Care 
men's health facility, youth from the White Earth 4-H, students from Minnesota State University, the

\section{Figure 1. Graph Displaying Results from a Question from the White Earth Food Sovereignty Survey Regarding Gardening Activities}

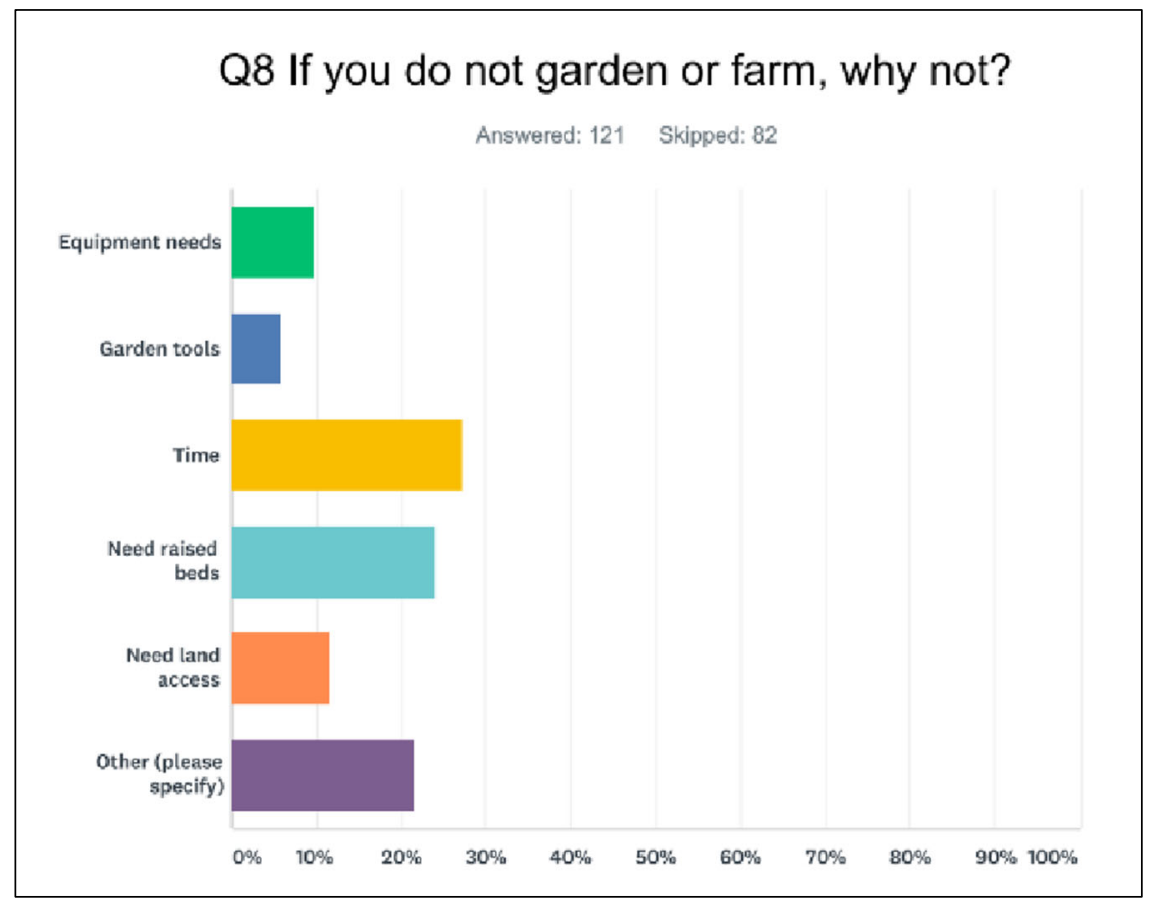

\section{Photo 2. Stanton Stanton Alexander with White Earth Youth Planting in a Three Sisters Traditional Garden System}

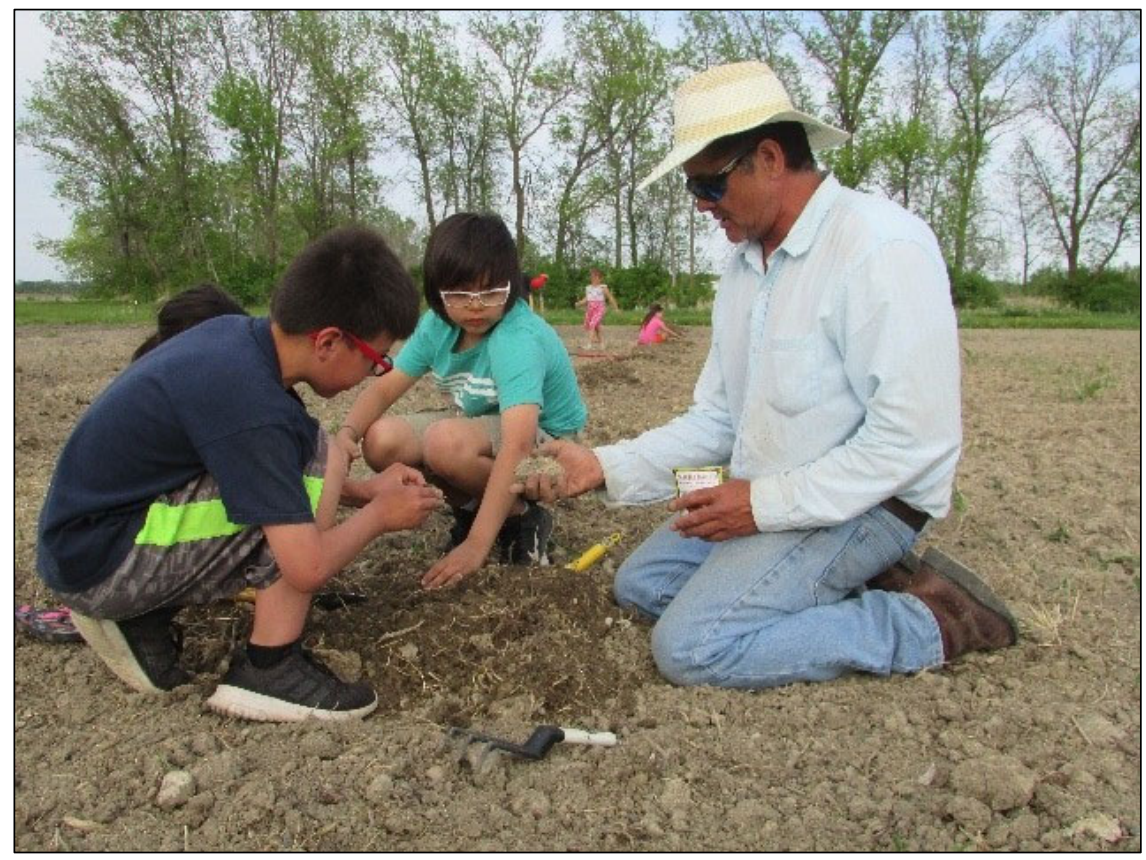

Photo by Zachary Paige. nonprofit Global Citizens Network, and others. We grew, cultivated, and harvested plots with the three sisters (corn, beans, squash) using traditional mounding system (Photo 2). With a family and elder program that met weekly, we went through the entire gardening process. We offered traditional seeds that we have been saving for years for people to choose from and plant. We grew a diverse range of vegetables, such as pumpkins, potatoes, peppers, and tomatoes, as well as strawberries in a low tunnel system to keep out weeds. We were also involved in a cover crop project led by Vivian Wauters from the Grossman Lab at the University of Minnesota, as well as a sweet corn taste test project from Iowa State University. The cover crop project showed which varieties of cover crops worked best in our soil type throughout the summer and demonstrated how they cool the soil, keeping soil microbes alive and adding organic matter to the soil. We held a community soil health day to showcase the results of this trial as well as to discuss soil health principals from both sustainable farming and traditional viewpoints.

To respond to another need identified in the survey (Figure 2), in 2018 we purchased a food truck to cook and distribute traditional healthy foods throughout the reservation. To support this project, we received funds 
from the Indian Health Service (IHS), First Nations Development Institute (FNDI), Good Food Access Fund (GFAF), and the White Earth Band of Minnesota Chippewa Tribe. We purchased our food truck from Sean Sherman, the Sioux Chef, and rebranded it with a design to show that we will not only be selling prepared traditional foods off the truck at events, but also will be a mobile grocery distribution unit. In the summer of 2018, we grew strawberries and ground cherries at our farm and used them in smoothies sold at the Mahnomen Farmer's Market and at the White Earth and Rice Lake pow wows to advertise the truck and showcase what we will be providing as a mobile market. We held meetings to showcase the truck in the communities in White Earth that have limited access to grocery stores, such as Rice Lake and Naytahwaush (and of course cooked a traditional meal at each one). We also got the community council's opinion on route schedules and drop-off points for the future mobile grocery. We are currently getting the truck up to par with improvements needed to hold grocery foods, and figuring out staffing, drivers, and our route, as well as applying to USDA to accept SNAP and WIC dollars. We are also purchasing from local and traditional producers some traditional food items that we plan on selling off the mobile market, such as wild rice, maple syrup, dried berries, wild herbs as teas, and many more items. Some of the traditional food items, such as tribally produced popcorn and olive oil from outside reservations, may be purchased from our Intertribal Agriculture Council technical assistant, Dan Cornelius, who has started a mobile traditional farmer's market of his own.

There are other projects happening, such as bison and hemp programs that are just getting some footing. The big picture for the White Earth
Agriculture Department is to continue to grow out more traditional seeds on more acreage and provide White Earth businesses with traditional foods such as corn, beans, squash, popcorn, and more to package and sell back to community members at an affordable price. We also grow out and keep pure many varieties of old seeds that are very often higher in nutrition than conventional hybrids. The hemp program has the potential to supply up to 25 more jobs, as well as the opportunity to grow and produce hemp as an agricultural product on a medium to large scale. At this time, when there is a trend of eating healthy and growing interest in food justice and food sovereignty in our country, we are able to utilize the movement of these efforts to gain support primarily from young people of privilege as they recognize the disparity of wealth provided to people of color in this country for centuries.

Along with our food sovereignty meetings, we use many forms of outreach to the community to get the word out on what we do. One way we do this is through our tilling program, in which we tilled over 60 community members' gardens in 2018 and provided gardeners with access to seeds. We post articles on social media, on the radio, and through our tribal newspaper. We host events throughout the year at our White Earth Commu- 
nity Farm in Mahnomen, Minnesota. We also host the annual Indigenous Farming Conference gathering, where representatives of many food sovereignty programs meet and discuss their stories. It is always an enlightening time to visit and partake in hands-on activities. The theme of the 2019 conference is Aanji-bimaajitoon Gidibaajimowininaan (Revitalizing Our Story).

\section{Resources}

\section{Articles:}

- NPR Morning Edition episode, White Earth hopes food truck puts reservation on road to better health: https://www.mprnews.org/story/2018/07/27/white-earth-minnesota-food-truck-native-health-sioux-chef

- NPR Morning Edition episode, White Earth tribe holds high hopes for hemp: https://www.mprnews.org/story/2017/08/09/white-earth-tribe-high-hopes-hemp

\section{Videos:}

- Minnesota's Good Food Access Program Profile: White Earth: https://youtu.be/E_9aottj1n4

- Minnesota's Good Food Access Program: https://youtu.be/u0qjAaDW3BY 